\title{
Measurement of Magnetic Field from Electrical Appliances in EEE Classrooms of Southeast University Bangladesh
}

\author{
Munima Haque*, Md. Quamruzzaman \\ Department of Electrical and Electronic Engineering (EEE), Southeast University, Bangladesh
}

Copyright $(2016$ by authors, all rights reserved. Authors agree that this article remains permanently open access under the terms of the Creative Commons Attribution License 4.0 International License

\begin{abstract}
The aim of this survey is to investigate whether the Electromagnetic Fields (EMF) emitted from various air conditioners and switch boards affect the students, faculties and employees. There is a standard threshold value recommended by World Health Organization (WHO) for both electric and magnetic fields. Electro-Magnetic Fields commonly known as Non Ionizing Radiation is emitted from high power transmission lines, computer monitor/video display unit, radio waves of different frequencies (extremely low frequency to microwaves), telecommunication, satellite, radar etc. which causes health hazards to living system and environment. There has not been much study performed in Bangladesh. The data were collected from various Electrical and Electronic department classrooms at Southeast University in Dhaka, Bangladesh. Both threshold values of Electric and Magnetic fields were measured for various air conditioners and switchboards. The maximum value of the magnetic field results showed that in many cases the magnetic field radiated from the different sources are greater than the threshold limit, which are the main point of our findings.
\end{abstract}

Keywords EMF, NIR, WHO, ELF, EF, MF

\section{Introduction}

Ionizing radiation is the radiation of sufficiently high energy to cause ionization in the medium through which it passes. It may consist of a stream of high-energy particle (e.g. electron, protons, alpha particles) or short wavelength electromagnetic radiation (ultraviolet, X-rays, gamma-rays). Radiation, which does not cause any ionization of the media while passing through it, is known a non-ionizing radiation (NIR). Examples of non-ionizing radiation are ultraviolet, visible light, infrared, microwave and radiowave. Their energy is relatively low; it only manages to cause molecules to vibrate and induces heating effects.
Exposure to Extremely Low Frequency (ELF) electric and magnetic fields does produce biological effects. However, except for fields strong enough to induce current densities above the threshold for the stimulation of nerve tissue, there is no consensus as to whether these effects constitute a hazard to human health. Human data from epidemiological studies, including reported effects on cancer promotion, congenital malformations, reproductive performance and general health, though somewhat suggestive to adverse health effects, are not conclusive. Magnetic fields associated with appliances are typically stronger than those fields found near power lines [1], there must be a limit both in the residential and occupational levels between 0.2 to $0.3 \mu \mathrm{T}$ or $2.5 \mathrm{mG}$. which are internationally recognized as standard limit in many countries. Also, for electric field this value is $25 \mathrm{~V} / \mathrm{m}$. It must be ensured that intensity of radiation in the body does not exceed the recommended maximum level (10 $\mathrm{mW} / \mathrm{cm}^{2}, 195 \mathrm{~V} / \mathrm{m}$ in U.S.A. and $0.1 \mathrm{~mW} / \mathrm{cm}^{2}, 20 \mathrm{~V} / \mathrm{m}$ in CIS). [2-3]. Electric fields can be blocked by most objects (e.g. trees, the ground, buildings etc.) However, magnetic fields pass through most objects. This is one reason why burying power lines will not necessarily eliminate magnetic fields. As most scientific research and public issues have focused on measuring magnetic fields[1], in this study the magnetic field has been measured.

Lower animals are reported to very much sensitive to electromagnetic fields. It is observed that animals like rats make their living brooding holes away from the high electric field and bees block-up their hives in the chronic presence of NIR/EMF. As a consequence, scientists and health physicians in developed countries have become aware of the effects of NIR [4]. Their research and observations have brought out some remarkable results linking low level alternating electromagnetic fields with serious health hazards. There is also evidence that biological effect like immune deficiency, sensitive lymphocytes, disrupting DNA, cellular breakdown is being affected by NIR [5].

Leukaemia and exposure to EMF are discussed in Savitz works [6]. Also, there have been studies of childhood cancer 
due toEMF exposure. [7]. Exposure of Magnetic Fields Alternating at Extremely Low Frequency is also discussed [8]. There have been studies on Environmental power-frequency magnetic fields and suicide. [9]. There has also been an investigation performed on Stray voltage and developmental, reproductive and other toxicology problems in dogs, cats and cows. [10]. RF-field interactions with biological systems are investigated. [11]

Much research has been performed in this regard. Most recently, Epidemiological survey of people working in EMF field exposed to high frequency have been investigated [12]. Also, research was performed for epidemiological survey on effect of EMF emitted by photocopy machines generally used in Dhaka city Bangladesh [13]. Survey was done on EMF emitted by Lab equipments in various labs of Southeast University in Bangladesh for possible health hazards [14]. A case study was done on EMF near high voltage transmission line [15]. Also, a review was done on Non Ionizing Radiation (NIR), its harmful effects especially from Mobile/Cell Phone and Towers [16]. An epidemiological survey was performed on CRT monitors used in Dhaka city [17]. Measurement of EMF was also done on Pharmacy Lab equipments in Southeast University [18]

There have been various papers published on EMF of radio, TV etc. but not much on Air Conditioners (AC). Since the invention of modern electrical air conditioning unit in 1902 by Willis Carrier, Buffalo, New York [19] there has been tremendous increase in use of air conditioning in the world. In some cases it has been used in cooling the building, theatres, and for commercial purposes. Since air conditioner has been used for comfort, its demand has increased. After the invention of portable air conditioners, it has been easier to purchase one. Especially in tropical countries like Bangladesh, it is in high demand not only at offices, but at homes also. With the increase in the efficiency of the modern air conditioners as well as the attractive decrease in its price, offices and private homes have their own air conditioner systems. At Southeast University, all the offices, labs and classrooms have air conditioners due to very hot and humid weather during the summer. Each office, labs and classrooms have one or multiple switchboards. The students spend around 7-8 hours each day in these classrooms and labs while the faculties and employees also do the same. The aim of this research is to investigate whether the EMF emitted from these air conditioners and switchboards are within threshold values and also if the students and employees are safe from these equipment.

\section{Materials and Methods}

A Cornet ED78S EMF RF Meter ElectroMagnetic Detector [20] was used for measuring the magnetic field values for the various air conditioners and switch board equipments. A Coghill Field Mouse for Biohazard Awareness was used for measuring the threshold values for both electric field (EF) and magnetic field (MF) around the instrument. The threshold voltage setup inside the Coghill Field Mouse is according to ICNIRP. The readings were taken to cover all around the equipment. The method followed was: at the center of the equipment (front side), upper backside, at $45^{\circ}$ both front side and back.
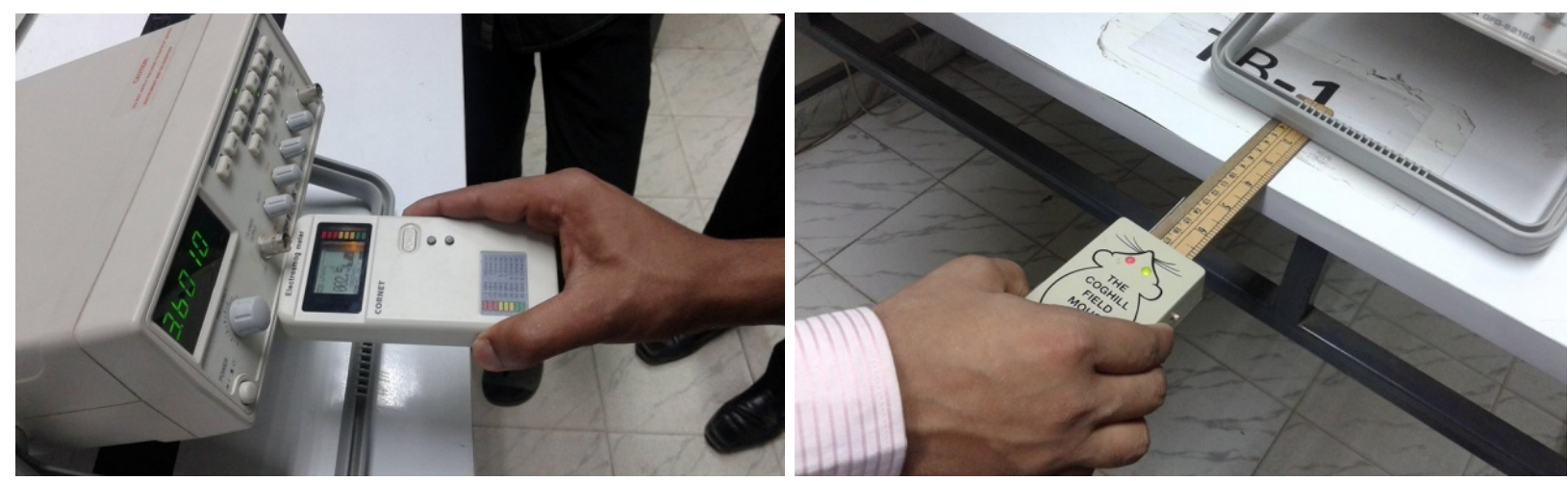

Figure 1. Electrosmog RF/LF Field Strength power meter Dual mode RF power meter \& LF gauss meter ED-78S measuring magnetic field in front of equipment (left image) and the COGHILL FIELD MOUSE measuring the EF and MF threshold values (see the red and green lights). Green light indicates the EF threshold has reached while the MF threshold reading still showing red i.e. not reached threshold yet. [right image] 


\section{Results}

Findings at different EMF sources: All the readings were taken from different classrooms of Electrical and Electronic Engineering (EEE) department, Southeast University Tejgaon Permanent campus. EEE department is located in $4^{\text {th }}$ floor and $5^{\text {th }}$ floor, Tejgaon campus, Southeast University. Readings were taken from air conditioning units and the switchboards of each classroom.

Table 1. EMF values measured for Air Conditioner equipments in various EEE classrooms in Southeast University (SEU), December 2015. Air Conditioner location address: (1) Classroom MC 408, (2) classroom MC 411, (3) classroom MC 413, (4) classroom MC 504, (5) classroom MC 507, (6) classroom MC 509, (7) classroom MC 405, (8) classroom MC 410.

\begin{tabular}{|c|c|c|c|c|c|c|c|c|}
\hline $\begin{array}{l}\text { Serial } \\
\text { No. }\end{array}$ & $\begin{array}{l}\text { Equipment info. } \\
\text { (Machine \#, Machine } \\
\text { Model, made country, } \\
\text { year made, Date of } \\
\text { installation) }\end{array}$ & $\begin{array}{l}\text { Threshold } \\
\text { dis. front of } \\
\text { equipment } \\
\text { measured } \\
\text { from the } \\
\text { centre }(\mathrm{cm}) \\
\text { EF } \\
\end{array}$ & $\begin{array}{l}\text { Magnetic } \\
\text { Field }(\mathrm{mG}) \\
\text { in front of } \\
\text { the eqpt. }\end{array}$ & $\begin{array}{l}\text { Threshold } \\
\text { dis. at right } \\
\text { side of the } \\
\text { equipment } \\
\text { (cm) EF }\end{array}$ & $\begin{array}{l}\text { Magnetic } \\
\text { Field (mG) } \\
\text { at right side } \\
\text { of the } \\
\text { equipment }\end{array}$ & $\begin{array}{l}\text { Threshold } \\
\text { distance at the } \\
\text { left side of the } \\
\text { equipment }(\mathrm{cm}) \\
\text { EF }\end{array}$ & $\begin{array}{l}\text { Magnetic } \\
\text { Field (mG) } \\
\text { at left side } \\
\text { of the } \\
\text { equipment }\end{array}$ & $\begin{array}{l}\text { Magnetic } \\
\text { Field } \\
\text { maximum } \\
(\mathrm{mG})\end{array}$ \\
\hline 1 & $\begin{array}{c}\text { Power- } 3 \text { ton } \\
\text { Brand: Carrier } \\
\text { Model: } 38 \text { VTA } 040 \\
\text { ‥90125 Phase-3, } 50 \mathrm{~Hz} \\
\text { Ins. Date: } 5-5-2014 \\
\end{array}$ & $3 \mathrm{~cm}$ & $4 \mathrm{mG}$ & $2 \mathrm{~cm}$ & $3 \mathrm{mG}$ & $3 \mathrm{~cm}$ & $4 \mathrm{mG}$ & $4 \mathrm{mG}$ \\
\hline $2 \mathrm{a}$ & $\begin{array}{c}\text { Power- } 3 \text { ton } \\
\text { Brand: Carrier } \\
\text { Model: } 38 \text { VTA } 040 \\
\text {..90125 Phase-3 } \\
\text { Ins. Date: } 5-5-2014\end{array}$ & $4 \mathrm{~cm}$ & $5 \mathrm{mG}$ & $3 \mathrm{~cm}$ & $4 \mathrm{mG}$ & $3 \mathrm{~cm}$ & $4 \mathrm{mG}$ & $5 \mathrm{mG}$ \\
\hline $2 b$ & $\begin{array}{c}\text { Power- } 3 \text { ton } \\
\text { Brand: Carrier } \\
\text { Model: } 38 \text { VTA } 040 \\
\text {..90125 Phase-3, } 50 \mathrm{~Hz} \\
\text { Ins. Date: } 5-5-2014\end{array}$ & $2 \mathrm{~cm}$ & $11 \mathrm{mG}$ & $2 \mathrm{~cm}$ & $10 \mathrm{mG}$ & $3 \mathrm{~cm}$ & $12 \mathrm{mG}$ & $12 \mathrm{mG}$ \\
\hline 3 & $\begin{array}{c}\text { Power- } 3 \text { ton } \\
\text { Brand: Carrier } \\
\text { Model: } 38 \text { VTA } 040 \\
\text {..90125 Phase-3, } 50 \mathrm{~Hz} \\
\text { Ins. Date: } 5-5-2014\end{array}$ & $3 \mathrm{~cm}$ & $4 \mathrm{mG}$ & $3 \mathrm{~cm}$ & $4 \mathrm{mG}$ & $3 \mathrm{~cm}$ & $3 \mathrm{mG}$ & $4 \mathrm{mG}$ \\
\hline 4 & $\begin{array}{c}\text { Power- } 3 \text { ton } \\
\text { Brand: Carrier } \\
\text { Model: } 38 \text { VTA } 040 \\
\text {..90125 Phase-3, } 50 \mathrm{~Hz} \\
\text { Ins. Date: } 5-5-2014 \\
\end{array}$ & $3 \mathrm{~cm}$ & $4 \mathrm{mG}$ & $4 \mathrm{~cm}$ & $4 \mathrm{mG}$ & $5 \mathrm{~cm}$ & $3 \mathrm{mG}$ & $4 \mathrm{mG}$ \\
\hline 5 & $\begin{array}{l}\text { Power- } 2 \text { ton } \\
\text { Old type }\end{array}$ & $3 \mathrm{~cm}$ & $7 \mathrm{mG}$ & $2 \mathrm{~cm}$ & $5 \mathrm{mG}$ & $2 \mathrm{~cm}$ & $8 \mathrm{mG}$ & $8 \mathrm{mG}$ \\
\hline 6 & $\begin{array}{l}\text { Power- } 2 \text { ton } \\
\text { Old type }\end{array}$ & $4 \mathrm{~cm}$ & $8 \mathrm{mG}$ & $2 \mathrm{~cm}$ & $6 \mathrm{mG}$ & $2 \mathrm{~cm}$ & $7 \mathrm{mG}$ & $8 \mathrm{mG}$ \\
\hline 7 & $\begin{array}{c}\text { Power- } 3 \text { ton } \\
\text { Brand: Carrier } \\
\text { Phase-3, } 50 \mathrm{~Hz} \\
\text { Ins. Date: } 5-5-2014\end{array}$ & $22 \mathrm{~cm}$ & $2.3 \mathrm{mG}$ & $2 \mathrm{~cm}$ & $5 \mathrm{mG}$ & $14 \mathrm{~cm}$ & $26.5 \mathrm{mG}$ & $26.5 \mathrm{mG}$ \\
\hline $8 a$ & $\begin{array}{c}\text { Power- } 2.5 \text { ton } \\
\text { Brand: Carrier } \\
\text { Ins. Date: } 5-5-2014\end{array}$ & $0 \mathrm{~cm}$ & $10.2 \mathrm{mG}$ & $6 \mathrm{~cm}$ & $0.4 \mathrm{mG}$ & $22.5 \mathrm{~cm}$ & $47.2 \mathrm{mG}$ & $47.2 \mathrm{mG}$ \\
\hline $8 b$ & $\begin{array}{c}\text { Power- } 2.5 \text { ton } \\
\text { Brand: Carrier } \\
\text { Ins. Date: } 5-5-2014\end{array}$ & $0 \mathrm{~cm}$ & $11.4 \mathrm{mG}$ & $4 \mathrm{~cm}$ & $2.1 \mathrm{mG}$ & $14.5 \mathrm{~cm}$ & $5.1 \mathrm{mG}$ & $11.4 \mathrm{mG}$ \\
\hline
\end{tabular}


Table 2. EMF values measured for switchboards in various EEE classrooms in Southeast University (SEU), December 2015. Switchboards location address: (1) Classroom MC 408, (2) classroom MC 411, (3) classroom MC 413, (4) classroom MC 504, (5) classroom MC 507, (6) classroom MC 509, (7) classroom MC 405, (8) classroom MC 410, (9) classroom 415.

\begin{tabular}{|c|c|c|c|c|c|c|c|c|}
\hline $\begin{array}{l}\text { Serial } \\
\text { No. }\end{array}$ & $\begin{array}{l}\text { Equipment info. } \\
\text { (Machine \#, } \\
\text { Machine Model, } \\
\text { made country, } \\
\text { year made, Date of } \\
\text { installation) }\end{array}$ & $\begin{array}{l}\text { Threshold dis. in } \\
\text { front of the screen } \\
\text { measured from the } \\
\text { centre of the } \\
\text { equipment }(\mathrm{cm}) \\
\mathrm{EF}\end{array}$ & $\begin{array}{l}\text { Magnetic } \\
\text { Field. } \\
\text { measured } \\
\text { from the } \\
\text { centre of the } \\
\text { equipment } \\
\text { (mG) }\end{array}$ & $\begin{array}{c}\text { Threshold } \\
\text { dis. at } 45^{\circ} \\
\text { angle from } \\
\text { the normal } \\
\text { drawn at the } \\
\text { centre }(\mathrm{cm}) \\
\text { EF }\end{array}$ & $\begin{array}{c}\text { Magnetic } \\
\text { Field at } \\
45^{\circ} \text { angle } \\
\text { from the } \\
\text { normal } \\
\text { drawing at } \\
\text { the centre } \\
(\mathrm{mG})\end{array}$ & $\begin{array}{l}\text { Threshold } \\
\text { distance at } \\
\text { the top of the } \\
\text { equipment(c } \\
\text { m) EF }\end{array}$ & $\begin{array}{l}\text { Magnetic } \\
\text { Field at the } \\
\text { top of the } \\
\text { equipment } \\
\text { (mG) }\end{array}$ & $\begin{array}{l}\text { Magnetic } \\
\text { Field } \\
\text { maximum } \\
(\mathrm{mG})\end{array}$ \\
\hline $1 \mathrm{a}$ & Switchboard & $18 \mathrm{~cm}$ & $14 \mathrm{mG}$ & $17 \mathrm{~cm}$ & $15 \mathrm{mG}$ & $18 \mathrm{~cm}$ & $13 \mathrm{mG}$ & $15 \mathrm{mG}$ \\
\hline $1 \mathrm{~b}$ & 13 A Socket & $12 \mathrm{~cm}$ & $11 \mathrm{mG}$ & $13 \mathrm{~cm}$ & $10 \mathrm{mG}$ & $12 \mathrm{~cm}$ & $12 \mathrm{mG}$ & $12 \mathrm{mG}$ \\
\hline $2 a$ & Switchboard & $16 \mathrm{~cm}$ & $14 \mathrm{mG}$ & $17 \mathrm{~cm}$ & $14 \mathrm{mG}$ & $17 \mathrm{~cm}$ & $14 \mathrm{mG}$ & $14 \mathrm{mG}$ \\
\hline $2 b$ & 13A socket & $12 \mathrm{~cm}$ & $11 \mathrm{mG}$ & $13 \mathrm{~cm}$ & $10 \mathrm{mG}$ & $12 \mathrm{~cm}$ & $12 \mathrm{mG}$ & $12 \mathrm{mG}$ \\
\hline $3 a$ & Switchboard & $18 \mathrm{~cm}$ & $15 \mathrm{mG}$ & $17 \mathrm{~cm}$ & $15 \mathrm{mG}$ & $18 \mathrm{~cm}$ & $13 \mathrm{mG}$ & $15 \mathrm{mG}$ \\
\hline $3 b$ & 13A socket & $12 \mathrm{~cm}$ & $11 \mathrm{mG}$ & $13 \mathrm{~cm}$ & $10 \mathrm{mG}$ & $12 \mathrm{~cm}$ & $12 \mathrm{mG}$ & $12 \mathrm{mG}$ \\
\hline $4 \mathrm{a}$ & Switchboard & $17 \mathrm{~cm}$ & $14 \mathrm{mG}$ & $17 \mathrm{~cm}$ & $15 \mathrm{mG}$ & $16 \mathrm{~cm}$ & $14 \mathrm{mG}$ & $15 \mathrm{mG}$ \\
\hline $4 \mathrm{~b}$ & $13 \mathrm{~A}$ socket & $13 \mathrm{~cm}$ & $12 \mathrm{mG}$ & $13 \mathrm{~cm}$ & $10 \mathrm{mG}$ & $14 \mathrm{~cm}$ & $13 \mathrm{mG}$ & $13 \mathrm{mG}$ \\
\hline $5 \mathrm{a}$ & Switchboard & $18 \mathrm{~cm}$ & $15 \mathrm{mG}$ & $17 \mathrm{~cm}$ & $16 \mathrm{mG}$ & $18 \mathrm{~cm}$ & $13 \mathrm{mG}$ & $16 \mathrm{mG}$ \\
\hline $5 b$ & $13 \mathrm{~A}$ socket & $10 \mathrm{~cm}$ & $12 \mathrm{mG}$ & $12 \mathrm{~cm}$ & $11 \mathrm{mG}$ & $12 \mathrm{~cm}$ & $14 \mathrm{mG}$ & $14 \mathrm{mG}$ \\
\hline $6 a$ & Switchboard & $14 \mathrm{~cm}$ & $12 \mathrm{mG}$ & $13 \mathrm{~cm}$ & $12 \mathrm{mG}$ & $15 \mathrm{~cm}$ & $13 \mathrm{mG}$ & $13 \mathrm{mG}$ \\
\hline $6 \mathrm{~b}$ & $13 \mathrm{~A}$ socket & $10 \mathrm{~cm}$ & $9 \mathrm{mG}$ & $12 \mathrm{~cm}$ & $10 \mathrm{mG}$ & $12 \mathrm{~cm}$ & $9 \mathrm{mG}$ & $10 \mathrm{mG}$ \\
\hline $7 a$ & $\begin{array}{c}\text { Switch board }-2 \\
\text { No. of switch: } 16\end{array}$ & $18 \mathrm{~cm}$ & $2.8 \mathrm{mG}$ & $1 \mathrm{~cm}$ & $0.6 \mathrm{mG}$ & $1 \mathrm{~cm}$ & $0.5 \mathrm{mG}$ & $2.8 \mathrm{mG}$ \\
\hline $7 \mathrm{~b}$ & $\begin{array}{c}\text { Socket point } 14 \\
13 \mathrm{~A}-9,10 \mathrm{~A}-5\end{array}$ & $7 \mathrm{~cm}$ & $0.1 \mathrm{mG}$ & $1 \mathrm{~cm}$ & $0.2 \mathrm{mG}$ & $1 \mathrm{~cm}$ & $0.3 \mathrm{mG}$ & $0.3 \mathrm{mG}$ \\
\hline $8 \mathrm{a}$ & Switch board & $3.5 \mathrm{~cm}$ & $1.2 \mathrm{mG}$ & $0.7 \mathrm{~cm}$ & $0.9 \mathrm{mG}$ & $1 \mathrm{~cm}$ & $1.2 \mathrm{mG}$ & $1.2 \mathrm{mG}$ \\
\hline $8 \mathrm{~b}$ & 13A socket & $4.3 \mathrm{~cm}$ & $3.3 \mathrm{mG}$ & $0.8 \mathrm{~cm}$ & $3.4 \mathrm{mG}$ & $2.5 \mathrm{~cm}$ & $3.4 \mathrm{mG}$ & $3.4 \mathrm{mG}$ \\
\hline $9 a$ & Switch board & $8.5 \mathrm{~cm}$ & $0.8 \mathrm{mG}$ & $18.5 \mathrm{~cm}$ & $0.5 \mathrm{mG}$ & $1 \mathrm{~cm}$ & $1.2 \mathrm{mG}$ & $1.2 \mathrm{mG}$ \\
\hline $9 \mathrm{~b}$ & $13 \mathrm{~A}$ socket board & $1 \mathrm{~cm}$ & $0.4 \mathrm{mG}$ & $2 \mathrm{~cm}$ & $1.5 \mathrm{mG}$ & $3 \mathrm{~cm}$ & $2.2 \mathrm{mG}$ & $2.2 \mathrm{mG}$ \\
\hline
\end{tabular}

Table 3. EMF values measured for substation and generator in EEE department building in Southeast University (SEU), December 2015. Equipments location address: Ground floor, MC 215A, Tejgaon Permanent Campus, Southeast University.

\begin{tabular}{|c|c|c|c|c|c|c|c|c|c|c|c|}
\hline \multirow[t]{2}{*}{$\begin{array}{c}\text { Serial } \\
\text { No. }\end{array}$} & \multirow{2}{*}{$\begin{array}{l}\text { Equipment info. } \\
\text { (Machine \#, } \\
\text { Machine Model, } \\
\text { made country, } \\
\text { year made, Date } \\
\text { of installation) }\end{array}$} & \multicolumn{2}{|c|}{$\begin{array}{l}\text { Threshold dis. } \\
\text { in front of the } \\
\text { screen measured } \\
\text { from the centre } \\
(\mathrm{cm})\end{array}$} & \multirow{2}{*}{$\begin{array}{l}\text { Magnetic } \\
\text { Field. } \\
\text { measured } \\
\text { from the } \\
\text { centre } \\
\mathrm{mG}\end{array}$} & \multicolumn{2}{|c|}{$\begin{array}{l}\text { Threshold dis. at } \\
45^{\circ} \text { angle from the } \\
\text { normal drawn at } \\
\text { the centre }(\mathrm{cm})\end{array}$} & \multirow{2}{*}{$\begin{array}{c}\text { Magnetic } \\
\text { Field at } 45^{\circ} \\
\text { angle from the } \\
\text { normal } \\
\text { drawing at the } \\
\text { centre } \\
\text { mG }\end{array}$} & \multicolumn{2}{|c|}{$\begin{array}{l}\text { Threshold } \\
\text { distance at the } \\
\text { top of the } \\
\text { equipment }(\mathrm{cm})\end{array}$} & \multirow{2}{*}{$\begin{array}{l}\text { Magnetic } \\
\text { Field at } \\
\text { the top of } \\
\text { the } \\
\text { equipment } \\
\text { mG }\end{array}$} & \multirow[t]{2}{*}{$\begin{array}{l}\text { Magnetic } \\
\text { Field } \\
\text { maximu } \\
\mathrm{m}(\mathrm{mG})\end{array}$} \\
\hline & & EF & MF & & $\mathrm{EF}$ & MF & & $\mathrm{EF}$ & MF & & \\
\hline I & Substation & $56 \mathrm{~cm}$ & $20 \mathrm{~cm}$ & $176 \mathrm{mG}$ & $96 \mathrm{~cm}$ & $20 \mathrm{~cm}$ & $190 \mathrm{mG}$ & Wall & $20 \mathrm{~cm}$ & $26 \mathrm{mG}$ & $176 \mathrm{mG}$ \\
\hline II & Generator & $20 \mathrm{~cm}$ & $*$ & $85 \mathrm{mG}$ & $10 \mathrm{~cm}$ & $*$ & $46 \mathrm{mG}$ & $7 \mathrm{~cm}$ & * & $58 \mathrm{mG}$ & $58 \mathrm{mG}$ \\
\hline
\end{tabular}

\section{EMF Measurements from Air Conditioners}

In Table 1, experimental data of EMF values measured for Air Conditioner equipments were collected from the following classrooms: serial nos. (1) Classroom MC 408, (2) classroom MC 411, (3) classroom MC 413, (4) classroom MC 504, (5) classroom MC 507, (6) classroom MC 509, (7) classroom MC 405, (8) classroom MC 410, (9) classroom MC 415. Air conditioners (AC) brand "Carrier" - having 2, 2.5 and 3 tons of various models were measured for their Electric field and Magnetic field threshold distances as well as the magnetic field values for (i) in front of the equipment measured from the centre of the equipment (ii) at right side of the equipment and (iii) at left side of the equipment. Also, the maximum magnetic fields were measured for each $\mathrm{AC}$ of this lab. The "*" sign indicates that the threshold distance was above recommended level and out of range.

\section{EMF Measurements from Switch Boards}

In Table 2, experimental data were collected from the following classrooms: serial nos. (1) Classroom MC 408, (2) classroom MC 411, (3) classroom MC 413, (4) classroom MC 504, (5) classroom MC 507, (6) classroom MC 509, (7) 
classroom MC 405, (8) classroom MC 410, (9) classroom MC 415. Switch board, socket points were measured for their Electric field and Magnetic field threshold distances as well as the magnetic field values for (i) in front of the equipment measured from the centre of the equipment (ii) at right side of the equipment and (iii) at left side of the equipment. Also, the maximum magnetic fields were measured for each switch/boards of these labs. The "** sign indicates that the threshold distance was above recommended level and out of range.

\section{EMF Measurements from Substation and Generator}

In Table 3, experimental data were collected from the EMF values measured for substation and generator in EEE department building in Southeast University (SEU). Substation location address: Ground floor, MC 101, Tejgaon Permanent Campus, Southeast University and generator location address: Generator room, Tejgaon Permanent Campus, Southeast University. Substation and generator were measured for their Electric field and Magnetic field threshold distances as well as the magnetic field values for (i) in front of the equipment measured from the centre of the equipment (ii) at right side of the equipment and (iii) at left side of the equipment. Also, the maximum magnetic fields were measured for each switch/boards of these labs. The magnetic field threshold distance is beyond range i.e. "*” sign which indicates that the threshold distance was above recommended level and out of range. Therefore, was not given/shown in table 1 and table 2 and only given in table 3 .

In classroom MC 408, it has been observed that the (i) room temperature and the electric voltage supplied in Air Conditioners might be different: therefore, the EF and MF varied. (ii) There might be some problems in measurement using the EMF meter. In classroom MC 411, it has been observed that the (i) there were some problems to measure the accurate magnetic field and electric field because some pillars were situated beside the socket switch and distribution board. The magnitude of those measurements for these fields in meter was fluctuating which was confusing. In classroom MC 413, it has been observed that (i) there were not sufficient space around the Air Conditioner and so there were some problems to measure the accurate magnetic field and electric field and (ii) The scale was too short to measure the right side of the AC. From classroom MC 504, it has been observed that the (i) there were not sufficient space in that lab and so there were some problems to measure the accurate magnetic field and electric field threshold distance near the AC. From classroom MC 507, it has been observed that the (i) there were not sufficient space in that lab and so there were some problems to measure the accurate magnetic field and electric field distance and (ii) there were some problems taking reading with the switch. From classroom MC 509, it has been observed that it was difficult to measure the right side of the switch board and socket board because they were situated beside the pillar. From classroom 405, it has been observed that the (i) every element were close to each other for that reason it is difficult to get required value of $\mathrm{EF}$ and
MF of each element. (ii) It was very difficult to observe and count the unit value of the MF machine because fluctuation, at different times got different values.

\section{Discussions}

It was found from the results that the magnetic field values are much higher than the threshold level. Because of the nature of the wiring both in the ceiling and floor, all the rooms had higher magnetic field than threshold value. The magnetic field threshold distance is beyond range i.e. "**" sign which indicates that the threshold distance was above recommended level and out of range. Therefore, the magnetic field threshold was not given/shown in table 1 and table 2 . This value is only given in table 3 .

As Electric Field meter was not available and therefore, it was not possible to measure the Electric Field. Only, magnetic field could be measured. Also, as electric charge discharges with any metallic contact, or if the body is grounded, the object becomes neutral. But the magnetic field cannot be discharged, which resides inside the blood or tissue of animal body. Distances to the magnetic source were measured where the threshold value is met for verification.

Students work on an average of 7-8 hours a day in those classrooms. We have in mind to include classrooms from other departments of Southeast University for the study to continue. There has been an increase of use of the air conditioners in Bangladesh for the last few years in various offices and organizations to increase the working efficiency of the employees. For this reason, the load shedding of electricity has increased tremendously for the last few years due to excessive air conditioner used in offices, organizations and private homes for comfort living.

\section{Conclusions}

Results from the classroom, substation and generator, it has been found that in most cases the magnetic field has crossed threshold value. The magnetic field maximum exposure was neaarly $200 \mathrm{mG}$ in one case. Wiring must be done according to the building code 2012. As the locations of air conditioners were on the wall near to the roof, therefore because of this height (distance) students do not possess that much hazards as it should be. It is hoped that this survey will be helpful as a preventive health measure for students and employees of Southeast University.

\section{REFERENCES}

[1] Electric and Magnetic Fields (EMF) Duke Energy. https://www.duke-energy.com/pdfs/emf_brochure.pdf (accessed on 21.3.2016)

[2] Wertheimer N., Leeper, ED. Electrical wiring configurations 
and childhood cancer. American journal of Epidemiology1979; 109, 273-284.

[3] Milham, S. Mortality from leukaemia in workers exposed to electrical and magnetic fields. New English J Med. 1982; 307, 249.

[4] Repacholi, H. An Overview of WHO's EMF Project and the Health Effects of EMF Exposure. Proceedings of the International Conference on Non-Ionizing Radiation at UNITEN (ICNIR 2003), Electromagnetic Fields and Our Health.2003;1-13.

[5] Nordenson, I., Mild, K. H., Andersson, G. Sandström, M. Chromosomal aberrations in human amniotic cells after intermittent exposure to fifty hertz magnetic fields. Bioelectromagnetics. 1994;15, 293-301, 1994.

[6] Savitz, D.A. \& Calle. Leukemia and occupational exposure to electromagnetic fields. Journal of Occupational Medicine. 1987; Vol 29, pp. 47-51.

[7] Savitz. Childhood cancer and electromagnetic field exposure. Jopurnal of Epidemiology. 1988: Vol. 128, pp. 21-38.

[8] Beischer D.E. and Mitchell, R.E. Exposure of man to Magnetic Fields Alternating at Extremely Low Frequency. Aerospace Medical Research Laboratory. Pensacola, Florida, USA.

[9] Perry, F.S. Environmental power-frequency magnetic fields and suicide. Health Physics. 1981; 41, pp. 267-277.

[10] Marks TA, Ratke CC, English WO. Stray voltage and developmental, reproductive and other toxicology problems in dogs, cats and cows: a discussion. Vet Hum Toxicol. 1995 Apr;37 (2):163-72.

[11] Schwan, H.P. and Foster, K.R. RF-field interactions with biological systems. Proceedings of the Institute of Electrical \& Electronics Engineering. 1980; 68, 104-113.

[12] Quamruzzaman, M., Haque, M. Epidemiological Survey of People Working in EMF Field Exposed to High Frequency. Proceedings of the Global Engineering, Science and
Technology Conference 2012, 28-29 December, Dhaka, Bangladesh.

[13] Haque, M., Quamruzzaman, M. Epidemiological survey on effect of EMF emitted by photocopy machines generally used in Dhaka city Bangladesh. IJRET: International Journal of Research in Engineering and Technology. 2015; 4(4): 92-100.

[14] Haque, M., Quamruzzaman, M. Survey of EMF emitted by Lab equipments in various labs of Southeast University in Bangladesh for possible preventive health hazards. IFRSA International Journal of Electronics Circuits and Systems. 2015; 4(1): 26-32.

[15] Quamruzzaman, M. Haque, M., Ahmed, F.,Zaman, M.S. Effects of electromagnetic fields (EMF) near high voltage transmission line: a case study. Bangladesh Journal of Medical Physics. 2014; 7(1): 66-68.

[16] Quamruzzaman, M. Haque, M., Non Ionizing Radiation (NIR), its harmful effects especially from Mobile/Cell Phone and Towers. Southeast University Journal of Science and Engineering.2014; 8(1).

[17] Haque, M., Quamruzzaman, M. Survey on Effect of EMF Emitted by CRT Computer Monitors in Bangladesh. Universal Journal of Electrical and Electronic Engineering 2015; 3(5): 149-158.

[18] Haque, M., Quamruzzaman, M. Survey of EMF emitted by Lab equipments in Pharmacy labs of Southeast University in Bangladesh. International Journal of Research in Engineering and Technology (IJRET), 2015; 4(9): 13-17.

[19] History of air conditioning. US Department of Energy.Website:http://www.energy.gov/articles/history-air-c onditioning (accessed on 10-12-2015)

[20] Cornet ED78S EMF RF Meter ElectroMagnetic Detector (2015) http://www.radmeters.com/Cornet-ED78S-ep.html and http://www.amazon.com/Cornet-ED78S-Meter-Electro Magnetic-Detector/dp/B00P67QLA0/ref=sr_1_1?s=industria $1 \&$ ie $=$ UTF $8 \&$ qid $=1458266517 \&$ sr $=1-1 \&$ keywords $=$ Cornet (accessed on 21.3.2016) 